\title{
Social environmental vulnerability approach on the COVID-19 epoch: a case study in Blumenau (SC), Brazil
}

Análise de vulnerabilidade socioambiental na época da pandemia do COVID-19: um estudo de caso em Blumenau (SC), Brasil

Enfoque de vulnerabilidad socioambiental en la época del COVID-19: un estudio de caso en Blumenau (SC), Brasil

Received: 07/26/2021 | Reviewed: 07/31/2021 | Accept: 08/02/2021 | Published: 08/07/2021

Cristiane Mansur de Moraes Souza

ORCID: https://orcid.org/0000-0002-4586-7471 Fundação Universidade Regional de Blumenau, Brazil E-mail: arqcmansur@gmail.com

Bruno Jandir Mello

ORCID: https://orcid.org/0000-0003-1652-6157 Fundação Universidade Regional de Blumenau, Brazil E-mail: brunomelloarq@gmail.com

Luciano Félix Florit

ORCID: https://orcid.org/0000-0001-5437-8234 Fundação Universidade Regional de Blumenau, Brazil E-mail: lucianoflorit@gmail.com

Ângela Maria Cavalcanti Ramalho ORCID: https://orcid.org/0000-0002-8567-4367

Universidade Estadual da Paraíba, Brazil E-mail: angelamcramalho@gmail.com

Yasmin Mansur de Moraes Souza ORCID: https://orcid.org/0000-0003-3122-8705

Pontifícia Universidade Católica do Paraná, Brazil E-mail: yasminmansur@hotmail.com

Jéssica Teixeira Fraga Jeremias

ORCID: https://orcid.org/0000-0002-4451-8018 Fundação Universidade Regional de Blumenau, Brazil E-mail: arq.jessicajeremias@gmail.com Patrícia Dornelles de Aguiar

ORCID: https://orcid.org/0000-0003-4310-7353 Fundação Universidade Regional de Blumenau, Brazil E-mail: patidornelles.aguiar@gmail.com

\begin{abstract}
There is a strong correlation between poverty indicators and the occurrence of diseases associated with environmental inequalities; therefore, it is highly necessary to explore the linkages between these inequalities and COVID- 19. This article describes a research designs made to study aspects of social environmental vulnerability that underlies the linkages between inequalities and COVID-19. This article aims to address this linkage. The objective is to explore aspects of social environmental vulnerability that underlies a case study at Blumenau, Brazil. The analysis is based on the critical question: Is there a relationship between social environmental vulnerability and COVID-19 at Blumenau? In Blumenau, where the study was carry out, the poor people are more likely to be affected from the risks arising out of the location of their homes, and this situation increases their vulnerability to floods, landslides, lack of water and exposure to open sewage. The methodology was divide into two steeps: (i) analysis of multi-temporal spread pattern of COVID-19 around the site; and (ii) analysis of the social environmental vulnerability and COVID-19 relationship. Results have shown that in Blumenau, there is a relationship between social environmental vulnerability and COVID19. It can be said that COVID-19 emphases' the social environmental situation in Blumenau. Based on our experience, we contend that an effective way to examine the linkages between inequalities and COVID-19 is to employ concepts and theories drawn from existing research to support guidelines, indicators and methods.
\end{abstract}

Keywords: Social environmental vulnerability; COVID-19; Risk society; Anthropocene.

\section{Resumo}

Existe uma forte correlação entre os indicadores de pobreza e a ocorrência de doenças associadas às desigualdades socioambientais. Nesse sentido, é altamente necessário explorar essa correlação entre desigualdades socioambientais, 
expressa pela vulnerabilidade socioambiental, a qual tem aumentado consideravelmente após a pandemia do COVID19. Este artigo descreve um projeto de pesquisa, desenvolvido para analisar especificamente a relação entre vulnerabilidade socioambiental e o COVID-19 no caso do município de Blumenau, SC, Brasil. A análise parte da seguinte questão crítica: Existe correlação entre a vulnerabilidade socioambiental e o COVID-19 em Blumenau? Em Blumenau, onde foi realizado o estudo, a população de baixa renda familiar têm maior probabilidade de ser afetada pelos riscos decorrentes da localização de suas residências. Essa condição dessa população aumenta sua vulnerabilidade aos riscos socioambientais (enchentes, deslizamentos de terra, falta de água, exposição a esgoto a céu aberto, doenças etc.). A metodologia foi dividida em duas etapas: (i) análise do padrão de propagação multitemporal do COVID-19 e; (ii) análise da vulnerabilidade socioambiental e a relação com os óbitos por COVID-19. Os resultados mostraram que em Blumenau existe forte relação entre a vulnerabilidade socioambiental e o número de óbitos por COVID-19. Pode-se dizer que a COVID-19 enfatiza a crítica situação socioambiental de Blumenau. Com base nos resultados, pode-se afirmar que uma maneira eficaz de examinar as correlações entre desigualdades e COVID-19 é empregar conceitos e teorias extraídas de pesquisas empíricas, para elaborar diretrizes para a gestão de risco.

Palavras-chave: Vulnerabilidade socioambiental; COVID-19; Sociedade de risco; Antropoceno.

\section{Resumen}

Existe una fuerte correlación entre los indicadores de pobreza y la ocurrencia de enfermedades asociadas a las desigualdades socioambientales. Sin embargo, es necesario explorar los vínculos entre estas desigualdades durante la pandemia de COVID-19. Este artículo describe un proyecto de investigación, desarrollado para analizar los aspectos que establecen los vínculos entre la vulnerabilidad social y ambiental y el COVID-19. Este artículo tiene como objetivo abordar ese enlace. El objetivo de este artículo es explorar aspectos de vulnerabilidad social y ambiental en el estudio de caso en Blumenau, Brasil. El análisis parte de la siguiente pregunta crítica: ¿Existe una relación entre la vulnerabilidad social y ambiental y el COVID-19 en Blumenau? En Blumenau, donde se realizó el estudio, los pobres tienen más probabilidades de ser afectados por los riesgos derivados de la ubicación de sus viviendas, situación que aumenta su vulnerabilidad a los riesgos sociales y ambientales (inundaciones, deslizamientos de tierra, falta de agua, exposición a cielo abierto de aguas residuales, enfermedades, etc.). La metodología se dividió en dos pasos: (i) análisis del patrón de propagación multitemporal de COVID-19 y; (ii) análisis de la vulnerabilidad social y ambiental y su relación con las muertes por COVID-19. Los resultados mostraron que en Blumenau existe una peligrosa relación entre la vulnerabilidad social y ambiental y el COVID-19. Con base en nuestros resultados, se puede afirmar que es una forma efectiva de examinar las correlaciones entre desigualdades y COVID-19 y abordar conceptos y teorías extraídas de investigaciones empíricas, para elaborar pautas para la gestión de riesgos.

Palabras clave: Vulnerabilidad social y ambiental; COVID-19; Sociedad del riesgo; Antropoceno.

\section{Introduction}

Global warming and many human-driven changes to the environment are raising concerns not only in environmental and sustainability science, but also in all domains of science. Human activities have fundamentally altered the shape and the ecological functioning of the planet at local, regional, and global scales. This profound impact of humans on the natural world has been marked by a new geological era in the history of the Earth, the Anthropocene era (Crutzen \& Stoermer, 2000). The year 2020 was marked by the COVID-19 pandemic, which directly affected human well-being, the economy, with travel restrictions, closure of cities and borders and the suspension of social and cultural economic activities. These actions resulted almost immediately in an economic recession in several countries, especially those that failed to contain the internal spread of the disease.

Scientists are arguing that this actual pandemic is linked to anthropogenic action, which are producing social environmental impacts and are changing the balance of Earth system (Silva et. al., 2020). Pandemics have shown how urbanization have changed the way people are living and its relationship with other species. The consequences of the pandemics are even more perverse for countries of social inequalities, lack of sewage and health services and education difficulties of attending the population. Following this idea, scientists (Moser, 1998; Cutter, 2006; Adger, 2006) have argued the interdisciplinary character of the vulnerability concept. As so, vulnerability is been considered an important issue for the analysis of COVID-19's spread pattern within cities. 
As many researchers of the environmental justice emphasize, environmental inequality is undoubtedly one of the expressions of social inequality (Acselrad, 2018; Herculano, 2001). The poor people are more likely to be affected by the risks arising from the location of their homes, and this situation increases their vulnerability to floods, landslides, lack of water and exposure to open sewage. There is a strong correlation between poverty indicators and the occurrence of diseases associated with environmental inequalities; therefore, it is highly necessary to explore the linkages between these inequalities and COVID- 19. This article aims to address this linkage. The objective is to explore aspects of social environmental vulnerability that underlies the linkages between inequalities and COVID-19 outlining a case study in Brazil. The analysis is based on one critical question: Is there a relationship between social environmental vulnerability and COVID-19 at Blumenau?

\section{The Anthropocene Epoch and Challenges}

What is Anthropocene epoch, and why should vulnerability and COVID-19's approaches address our planet's geologic time scales? The term Anthropocene from the Greek word "anthropo", human and "cene", new, was coined by the ecologist Eugene Stoermer and popularized by chemist and Nobel Laureate Paul Crutzen to emphasize the scale of human footprint on the chemistry, biology, ecology, and geology of Earth's life support systems (Crutzen \& Stoermer, 2000). The Anthropocene is the current epoch in which human societies have become a global geophysical force. The Anthropocene began around 1800 with the onset of industrialization, the central feature of which was the enormous expansion in the use of fossil fuels (Steffen, Crutzen \& Mcneill, 2007).

The term Anthropocene suggests that the Earth has now left its previous natural geological epoch, the interglacial state called Holocene. It implies the period after which humanity became a geological actor, in biological soil (Dalby, 2015). Human activities have become so pervasive and profound that they rival the great forces of nature and are pushing the Earth into planetary terra incognita. The past century has seen the mass production and adoption of automobiles and electronics, large scale conversion of land to urban areas and agriculture, and an increase in the global population from 1.6 billion people in 1900, to over 7 billion in 2011 (MA, 2005; Steffen, Crutzen \& Mcneill, 2007).

The literature shows that Anthropocene epoch is thus far comprised of 3 stages: 1st stage - the industrial era (c.a. 1800-1945); 2sd stage - the great acceleration (c.a. 1945-? 2015); and the 3rd stage -Stewards of the Earth System (a.c. 2015?) (Mahaffy, 2014). The 1st stage is characterized by the industrialization of the earth system made possible by the rapid expansion in the extraction and use of fossil fuels such as coal and oil (Steffen, Crutzen \& Mcneill, 2007). The imprint on the global environment of the industrial era was, in retrospect, clearly evident by the early to mid-20th century (Steffen, Crutzen $\&$ Mcneill, 2007). The second stage consisted of the acceleration of the human enterprise after the end of the second world war and can be characterized by rapid changes in land use, desertification, loss of biodiversity, and changes to earth's water, nitrogen, and carbon cycles. Further, this phase saw population double in just 50 years, to over 6 billion by the end of the 20th century.

The 3rd stage that we are now entering, could be the turning point. Earth's life support system, ecosystem services and human induced pressures on this system is one of the greatest researches and policy challenges ever to confront humanity (Steffen, Crutzen \& Mcneill, 2007). At this stage, the epoch Anthropocene produces negative side effect such us loss of biodiversity, collapse of ecosystems, pandemics, disasters, climate change, global greenhouse effect and so on. At this stage of the Anthropocene epoch society is facing great change of the environmental conditions and to have deal with one of the biggest challenges the climate change, but as said by Beck, the problem is:

All of the discussion about climate change up till now has been focused on whether it is really happening, and if it is, what can we do to stop or contain or solve it? This is because we know it is an extremely time-sensitive issue. What 
no one has seen is that the focus on solutions blinds us to the fact that climate change has already changed the world our way of being in the world, our way of thinking about the world, and our way of imagining and doing politics. This change of the conditions and understandings of change I define as 'metamorphosis' (Beck, 2015, pp. 76).

What Beck (2015) called "metamorphosis", is a society affected by the changes that take place within the "risk society". At the society qualified by this sort of risk, mankind may find itself under the threat of a catastrophe, dangers situation (Goldblatt, 1996) or the collapse of ecosystem services. These services are called "eco-systemics" because they are benefits that people get from the interaction with nature (Reyers et al., 2013). The collapse of the eco-systemic services may turn into a social environmental catastrophe.

The millennium Ecosystem Assessment (MA, 2005) identified three ecosystem services core categories: (i) Provisioning services, such as water, crops, fish, cotton or timber; (ii) Regulating services, such as regulation of pests and diseases and climate regulation; and (iii) Cultural services, such as hiking, canoeing, sacred forests with cultural significance, or natural areas used for rites of passage (MA, 2005). Therefore, these services are essential to life. We all live and operate in social systems that are inextricably linked with the ecological systems in which they are embedded; we exist within social ecological systems (Walker \& Salt, 2006, p. 31) The collapse of this ecosystem push humanity to a risk society.

What is rick Society? The concept of risk is about a situation of uncertainty. It is also related to economic, social and environmental dimensions. In this context, there are challenges to be faced by society such us individualism, work relationship, unemployment growth, increase of violence indexes, ecological and instability of finance market global risks (Beck, 1999). This uncertainty has also its expression in some landscape configuration. This, however, is a factor in the disproportionate distribution of the effects of degradation, affecting even more the most vulnerable groups, as stated by Beck - "Climate change induces fundamentally changing landscapes of social class and inequality" (Beck, 2015, pp 76). The COVID-19's spread pattern is a sample of this inequality linkages, that shows its highly effect on human health and is currently spread within group of people with social environmental vulnerabilities.

The vulnerability concept refers to an approach of one part of the society to adapt to the currently epoch generated by the materialization of risk. It has a multidimensional character and it has been argued in an interdisciplinary way, due to its physical, environmental, and social dimensions. The concept of vulnerability precedes the identification of some social groups, since it requires specifying risks and determining both the response capacity to some risk and their ability to adapt to a new scenario (Rodríguez, 2001). At the risk society there are threats as: droughts, pandemics, loss of biodiversity and collapse of ecosystems combined with the inequalities. These inequalities are qualified as poverty, deficiencies in education, lack of basic sanitation, inefficiencies in health services and lack of democratic access to drinking water.

These sorts of inequalities' issue are currently found in Brazil and countries of major regional social environmental vulnerabilities, where the society groups and institutions COVID 19's response approach capacity is weak. Therefore, for these countries, it is argued that a social environmental vulnerability approach is important, to understand its linkages to the consequences of COVID 19. Brazil was the second country of the world of deaths numbers and the third of COVID-19 cases. In Brazil, 5,275,034 cases of COVID 19 were reported and the average of deaths were 154,891 people, 502 per day (till October 21) (LAGOM DATA, 2020). 61\% of the deaths were black and part of the socially vulnerable population, $70 \%$ were poor and the average age of the death were over 67 years old (SUS, 2020, at late August). 90\% of cases of infections by COVID-19 and deaths have taken place within cities, mainly in large ones. The federal strategy of managing COVID-19 is that each city and rural area have to manage the pandemic following its local character and particularities.

Therefore, a Blumenau's Social Environmental Vulnerability and its Mapping Relation to COVID-19 was design for this paper. It shows the actual relationship between each district of the city and deaths by COVID 19. The indicators considered were: Family income (IBGE, 2010), density (IBGE, 2010), \% age group over 45 year old (IBGE, 2010), lack of 
sewage (IBGE, 2010), bus transport (PMB, 2013), risk areas (floods and landslides) (PMB, 2013), number of death by COVID-19 (2020), within different districts of the city. The use of these indicators and its explanation for a social approach for inequalities is just the beginning of a larger discussion on the issue of the social environmental vulnerability process. The scope of this study was to develop a social environmental vulnerability approach to COVID-19 in Blumenau, Santa Catarina, Brazil, where Disasters, such as Floods and Landslides have been historically a threat. In the case of the currently Blumenau's Pandemic lack of infrastructure (supply of drinking water and sewage) makes some social groups to become vulnerable to this type of risk. Therefore, it is required further studies and scientific research about the vulnerable population living in slums.

\section{Study Case: Blumenau (SC)}

Blumenau has $518,619 \mathrm{~km}^{2}$ and an estimated population of 357.199 in 2019 ; its demographic density is 595,97 inhabitants $/ \mathrm{km}^{2}$. The average Human Development Index (HDI) is 0,806 (IBGE, 2019). The urban development process in Blumenau was shaped by the urban space occupation pattern. This urban sprawl pattern was, initially influenced by Blumenau's settlement and cultural establishment, which followed the Itajai-Açú river and some streams and the use of these water resources in agriculture. Afterwards, as Industrialization evolves, housing sites are also located near the industries and alongside rivers. With the increase of nature disasters in the last decade the effect of this process was a) the verticalization of meadow areas (gentrification by upper middle classes b) occupation of hillsides by lower classes. Therefore, middle classes are affected by floods and the poorer by landslides and downpours, or the vulnerability condition is also a social environmental relation.

According to the National Center for Monitoring and Natural Disaster Alerts, Blumenau has more than $23 \%$ of the population living in risk areas, occupying the 17th place in the national ranking (CEMADEN, 2018) In the region, there is already a certain preparedness of the community to disasters such as floods, which are historic. However, the biggest problem is in the lack of preparation to face the situations caused by the pandemic of COVID-19. In 2020, between March and September the city was strongly affected with more than 150 deaths and 13 thousand people contaminated. This problem may be related to the worsening of social environmental vulnerability conditions in the last decades. Blumenau is currently the largest city of the state of Santa Catarina on the number of slums. It holds 55 slums of more than 25 thousand people (IBGE, 2010). Another problem is sewage. According to the Brazilian Institute of Geography and Statistics (2010), more than 50\% of households do not have a treated sewage network and $7 \%$ of households do not have piped water.

For this study we consider the urban area of the city of Blumenau (SC), and its 5 regional sub-divisions. The subdivisions are: Garcia, Center, Fortaleza, Velha, Itoupavas (Figure 1) (IBGE, 2010) 
Figure 1 - Location of the case study, Blumenau (SC) and municipal subdivision.
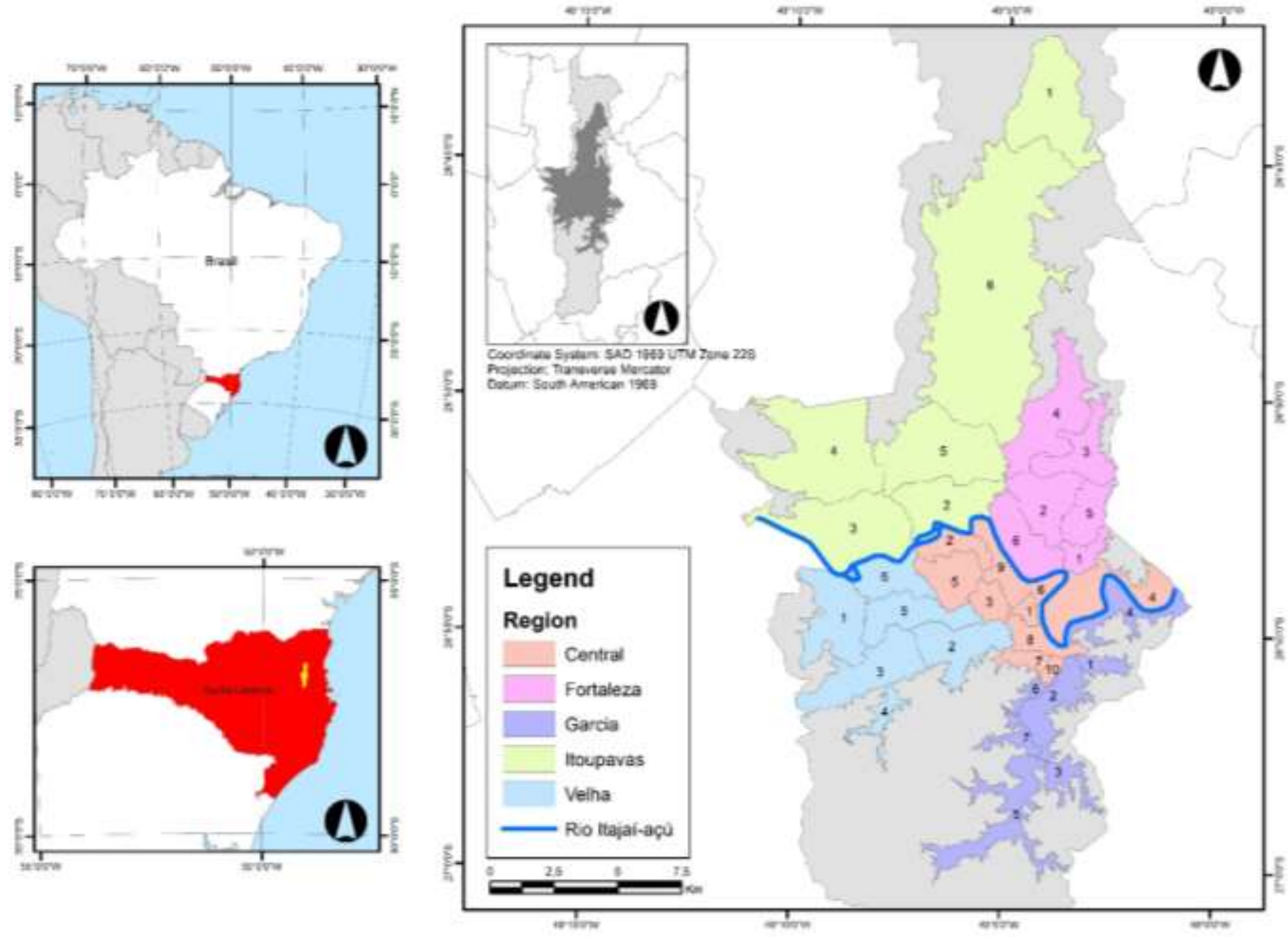

*The numbers correspond the name of the neighborhoods, see in table 2. Source: adapted from IBGE (2010).

\section{Methodology}

A qualitative character was report by the methodology. It is descriptive and explanatory, and its emphasis is on the spread pattern of the COVID-19 virus within the different social environmental vulnerability sites of Blumenau (SC) (Case in Study), applied to the timeframe of March $20^{\text {th }}$ to September $30^{\text {th }}, 2020$. The qualitative approach would allow to answer questions and to build an approach with a broad universe of meanings, aspirations, beliefs, values, and attitudes, which may correspond to a deeper space of relationships (Lüdke \& André, 1986; Yin, 2015). The qualitative method was applied for an event or phenomenon that is current on study. This methodology corresponds to a study of individual phenomena or social process (Pereira, et al., 2018). Blumenau was chosen for a case study, particularly because it has turned to be the main regional health center for COVID-19 care and treatment. In other words, the city has a very developed hospital infrastructure and is able to attend patients from different cities of the Santa Catarina state. In this sense, a collapse of Blumenau's health system may affect several cities at the region. The choice of Blumenau is also justified by the availability of COVID-19 database. The focus of a descriptive research may be to describe a phenomenon or situation, particularly what is taking place, allowing the exact coverage of the characteristics of an individual, a situation, as well as unraveling the relationship between events (SELLTIZ et al., 1965). An explanatory research may seek to connect ideas to understand causes and impacts. The focus of this research is to understand the relationship between social-environmental vulnerability and deaths caused by COVID-19 at the city of Blumenau. 
The methodology of this article was divide into two steps: the first one was (i) analysis of multi-temporal spread pattern of COVID-19 over Blumenau; and the second one was (ii) analysis of the social environmental vulnerability and COVID-19 relationship. At step one the data used for these steps, reflects the number of deaths and contamination rate at 2020, between March 20 $0^{\text {th }}$ and September $30^{\text {th }}$ around the city's site sub-division. These data used was provided by the city government health service (PMB, 2020). For the methodology of this research, a survey of confirmed cases and deaths by COVID-19 was conduct for the state of Santa Catarina (SANTA CATARINA, 2020) followed by an analysis of the spread of the disease in Blumenau. The Blumenau's data on the COVID-19 pandemic were displayed on a graph (Figure 2) and on a table with the following information: sub-division; district; neighborhood population; confirmed cases of COVID-19 in the neighborhood and; confirmed deaths in the neighborhood (table 2). At this stage, Microsoft Excel software was used to tabulate the data and display the results.

At the second step, an analysis of the social environmental vulnerability and COVID-19 relationship were carry out. For that, the methodology includes important factors for the spread of COVID 19 virus. It was five environmental, social, economic and urban infrastructure indicators. The indicators were divided into two main axes: a) social economic; b) social environmental (Table 1). The social environmental (IBGE, 2010) and the social economic indicators (PMB, 2013) were trace over the data of COVID-19 (PMB, 2020) of September $30^{\text {th }}$, 2020, resulting on four maps. The intention was to identify whether the population residing at the social and environmental vulnerable sites hold the highest number of deaths by the COVID 19. At the same time, the effectiveness of social environmental indicators applied to the spread of the virus would like could be research.

Table 1 - Social environmental vulnerability indicators to COVID-19 combined with deaths by COVID-19.

\begin{tabular}{lcc}
\hline Axes & \multicolumn{1}{c}{ Indicators } \\
\hline Social economic & Family income (IBGE, 2010) \\
\cline { 2 - 3 } & \% Age Group over 45 years (IBGE, 2010) \\
\hline Social environmental & Social Environmental Scenarios \\
\cline { 2 - 3 } & (Lack of sewage/ urban infrastructure/ slums areas) (PMB, 2013) \\
\cline { 2 - 3 } & Floods Map (PMB, 2013) & Risk Areas Map (Floods and Landslides) \\
(Authors, 2020)
\end{tabular}

Source: Authors (2020).

The results were traced on several maps combing data from the indicators for social-environmental vulnerability and data of Blumenau's confirmed death by COVID-19. The following map were: i) map of population density and COVID-19 deaths (Figure 3a); ii) map of \% of people over 45 years old that dead by COVID-19 in Blumenau (Figure 3b); III) map of social-environmental scenario and number of deaths by COVID-19 (Figure 4) and; iv) map of floods and landslides risk areas and COVID-19 deaths (Figure 5). To overly the of social-environmental vulnerability indicators and the COVID-19 data (PMB, 2020) on a cartography it was used the Geographic Information System software (ArcGIS 10.6). The Geographic Information System (GIS) is understood as a "computer-aided system for the acquisition, storage, analysis and visualization of geographic data" (Fitz, 2008, p. 23; Ludwig \& Mattedi, 2016, p. 9). GIS is used based on the collection and treatment of different types of data, which can be obtained from public databases or collected in the field by the user. Once acquired, the data is organized according to its objectives of analyses. Some data may undergo changes through georeferenced modeling, generating new information aimed for the specificity of its study. Through this process, the user may be able of crossing data 
by layers. By this process it is allowed to oversee new perceptions about the variables. It may be used for decision make processes.

At this research, the ZIP code database of people who died from COVID-19 (PMB, 2020) together with the socialenvironmental vulnerability indicator (IBGE, 2010; PMB, 2013) were traced on a cartographic data. This technique allowed us to analyze and characterize the most affected sub-regions, in addition to predicting which areas may be more impacted as the COVID-19 pandemic advances. It, therefore, allowed to understand that social-environmental vulnerability is an important factor for the increased number of deaths from COVID-19 at Blumenau. This methodology was adapted from the system of social vulnerability maps, agricultural networks, and the pandemic of COVID-19 in the State Santa Catarina from the Intersectoral Nucleus for Data Intelligence on Covid-19 of the State of Santa Catarina (EPAGRI, 2020).

\subsection{Indicators}

The social economic indicators (by census sector) used were: i) average family income; ii) population density (IBGE, 2010) and; iii) percentage of the population over 45 years old (IBGE, 2010). The average family income was selected because the population with the lowest income is the population with the greatest social vulnerability. This fact reflects the difficulty of some groups in adopting actions that could reduce their risk to COVID 19, such as social distance and personal hygiene care. The use of population density indicator is justified by the fact that more densely populated areas are more vulnerable to the spread of contagious diseases (Moore et al., 2017). According to Imperial College (Ferguson et al., 2020) and the World Health Organization (Aylward \& Liang, 2020) the population over the age of 60 years old has a higher mortality rate for COVID 19. Therefore, the study considers for the analysis the percentage of the population over $45^{1}$ years old.

The social economic indicator used were: i) age group with the highest probability of hospitalization and the highest mortality rate resulting from COVID-19 (IBGE, 2010); ii) population income (IBGE, 2010); iii) number of people at the census sector $^{2}$ (IBGE, 2010); and iv) demographic density (IBGE, 2010). About the age group, international studies, especially those published by Imperial College (Ferguson et al., 2020) and the World Health Organization (Aylward \& Liang, 2020), have shown the age group with the highest probability of hospitalization and the highest mortality rate resulting from COVID19 are people over 60 years old. The second measure considered in the calculation of the vulnerability index is relate to the population's income. The population income may outline the difficulty, for some groups, of adopting actions to reduce their exposure to risk of get COVID 19, such as: i) social distance and ii) hand washing care. The choice for demographic density as an indicator is justified by the fact that more densely populated sites are more vulnerable to the spread of contagious diseases (Moore et al., 2017). The social environmental indicators are: i) social environmental scenarios; ii) Risk areas (floods and landslides). The lack of urban infrastructures exposes the population to different risks and the risk to get COVID-19. The lack of sanitation is a determining factor for the worsening of risk conditions, especially diseases and epidemics. One of the main guidelines, recommended in all situations to reduce the speed of transmission of the virus of COVID-19, refers to the maintenance of hygiene care (WHO, 2020). In addition, Wu et al. (2020) suggests that there is a possibility to find COVID-19 at the feces of patients, around five weeks after breathing tests had been say negative.

\footnotetext{
${ }^{1}$ The data for the population age was from 2010, by Brazilian Institute of Geography e Statistics. In 2020, the population of 55 years old, was 45 years old in 2010. That's because it was considered, for this research, the age of 45 years old.

${ }^{2}$ Census sector is the geographic bit of land, selected where the survey is done, to count the number of people, number of people at the same home, and so on, by the Brazilian Institute of Geography and Statistics.
} 


\section{Results and Discussion}

\subsection{Social spatial diffusion of COVID-19 in Blumenau (SC)}

The state of Santa Catarina had its first case of COVID-19 on the $12^{\text {nd }}$ of March 2020 at Florianópolis. In the same month, the virus spread throughout the coastal region and in the largest cities in the interior of the state (Joinville: 650 thousand inhabitants; Blumenau: 355 thousand inhabitants; Chapecó: 150 thousand inhabitants). Until September $30^{\text {th }}, 2020$, there were 224 thousand cases and 2892 confirmed deaths, for a population of more than 6 million inhabitants in Santa Catarina. Blumenau is the third city of the state in number of infected people and is the second in number of deaths, according to data from the State Health Surveillance (September $30^{\text {th }}, 2020$ ). At Blumenau, the first case of contamination recorded, was recorded at $20^{\text {th }}$ of March. 20th case and the first death was on the $5^{\text {th }}$ of May, 2020. There are 151 deaths recorded and almost 14,000 cases of COVID-19 at the present date (September 30, 2020), (Figure 2). The Women are 53\% of those infected by COVID-19 in Blumenau, while men are 47\%. The age group that most got the disease was between 20 and 49 years old. From the 151 deaths in Blumenau, 64\% were of elderly men with heart conditions (PMB, 2020). At the time of this research, more than 55 thousand tests have been carried out and 12,751 people recovered, leaving 303 active cases (PMB, 2020).

Figure 2 - Confirmed cases and deaths of COVID-19 in Blumenau (SC) (2020, from March until September 30 ${ }^{\text {th }}$, 2020).

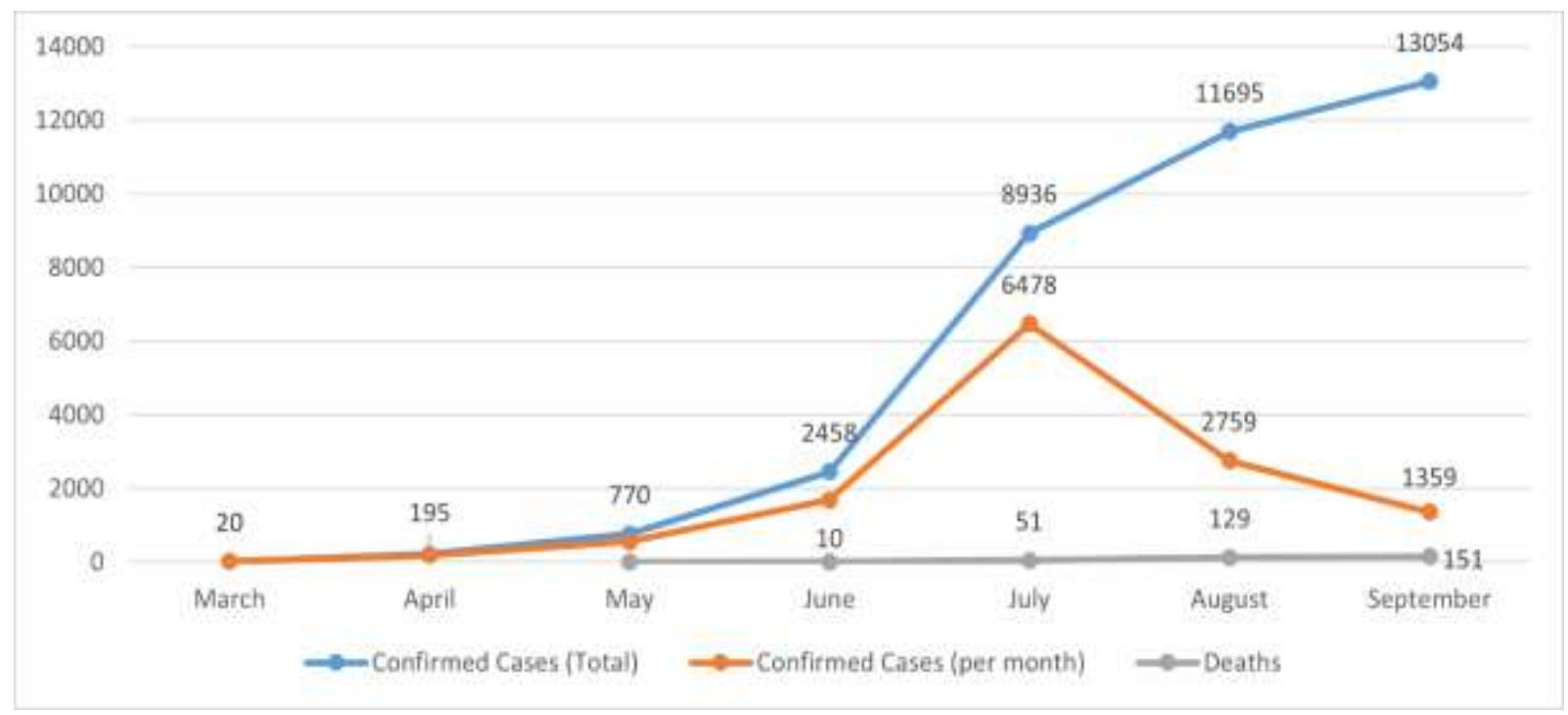

Source: PMB (2020).

The first case identified was a woman living at Blumenau's city center, who had come from Spain. At April, contagion was still concentrated in the central region. This month, the quarantine became more flexible, with the reopen of commerce and busses as a way of transport ( $22^{\text {nd }}$ of April). In May, the virus reached all neighborhoods of Blumenau. Still on the $5^{\text {th }}$ of May, the first death from the disease occurs. In June and July, with the arrival of winter, the greatest number of contamination and hospitalizations occurs. During this period, the municipal health system collapsed, and a lockdown decree was issued (July $20^{\text {th }}$ ). At August, contamination rates slow down, while the highest number of deaths occur, it was 80 . In September, there was a deceleration in the number of deaths and stabilization on the number of people with COVID-19

Blumenau's sub-divisions that recorded the highest number of infected and death by COVID-19 are (Table 2): i) the subdivision of Velha, a region with the largest number of people and more densest urbanized; ii) The Itoupavas subdivision, a region that holds the highest number of death by COVID-19 (33); iii) the Central region, where the pandemic began; iv) the 
neighborhoods in the subdivision of Fortaleza, the most vulnerable site to social environmental disasters and; v) the neighborhoods in the Garcia region, close to the city center.

Table 2 - Confirmed cases and deaths of COVID-19 in Blumenau's subdivisions (September 30, 2020).

\begin{tabular}{|c|c|c|c|c|}
\hline Subdivision & Neighborhood & Population & Confirmed Cases & Deaths \\
\hline \multirow{7}{*}{ I - Velha } & 1 - Passo Manso & 6.799 & 329 & 2 \\
\hline & 2 - Velha & 15.373 & 786 & 13 \\
\hline & 3 - Velha Central & 18.779 & 779 & 7 \\
\hline & 4 - Velha Grande & 4.332 & 263 & 3 \\
\hline & 5 - Água Verde & 16.186 & 744 & 5 \\
\hline & 6- Salto Weissbach & 5.213 & 190 & 2 \\
\hline & Total & 66.682 & 3.091 & 32 \\
\hline \multirow{11}{*}{ II - Central } & 1 - Victor Konder & 4.612 & 286 & 1 \\
\hline & 2 - Salto & 4.558 & 166 & 1 \\
\hline & 3 - Vila Nova & 9.962 & 421 & 3 \\
\hline & 4 - Ponta Aguda & 9.880 & 437 & 4 \\
\hline & 5 - Escola Agrícola & 12.145 & 576 & 9 \\
\hline & 6 - Boa Vista & 1.748 & 69 & 5 \\
\hline & 7 - Bom Retiro & 1.117 & 34 & - \\
\hline & 8 - Centro & 5.004 & 270 & 4 \\
\hline & 9 - Itoupava Seca & 4.464 & 303 & 4 \\
\hline & 10 - Jardim Blumenau & 2.855 & 239 & 1 \\
\hline & Total & 56.345 & 2.801 & 32 \\
\hline \multirow{7}{*}{ III - Fortaleza } & 1 - Nova Esperança & 3.853 & 160 & 1 \\
\hline & 2 - Fortaleza & 13.196 & 645 & 5 \\
\hline & 3 - Fortaleza Alta & 4.507 & 225 & 2 \\
\hline & 4 - Fidélis & 5.392 & 196 & 1 \\
\hline & 5 - Tribess & 8.503 & 347 & 4 \\
\hline & 6 - Itoupava Norte & 15.648 & 641 & 10 \\
\hline & Total & 51.099 & 2.214 & 23 \\
\hline \multirow[t]{7}{*}{ IV - Itoupavas } & 1 - Vila Itoupava & 1.319 & 146 & 1 \\
\hline & 2 - Salto do Norte & 8.441 & 305 & 4 \\
\hline & 3 - Badenfurt & 8.650 & 282 & 6 \\
\hline & 4 - Testo Salto & 7.065 & 262 & 2 \\
\hline & 5 - Itoupavazinha & 17.560 & 879 & 10 \\
\hline & 6 - Itoupava Central & 28.164 & 1.066 & 10 \\
\hline & Total & 71.199 & 2.940 & 33 \\
\hline \multirow{3}{*}{ V - Garcia } & 1. Ribeirão Fresco & 1.587 & 87 & - \\
\hline & $2-$ Garcia & 15.911 & 612 & 11 \\
\hline & 3 - Gloria & 6.228 & 226 & 4 \\
\hline
\end{tabular}




\begin{tabular}{|c|c|c|c|c|}
\hline Subdivision & Neighborhood & Population & Confirmed Cases & Deaths \\
\hline & 4 - Vorstadt & 4.269 & 203 & 5 \\
\hline & 5 - Progresso & 15.005 & 612 & 5 \\
\hline & 6 - Vila Formosa & 711 & 34 & - \\
\hline & 7 - Valparaíso & 5.280 & 234 & 6 \\
\hline & Total & 349.012 & 2.008 & 31 \\
\hline
\end{tabular}

Source: IBGE (2010); PMB (2020).

The Blumenau district subdivisions (Table 2) include all neighborhoods in the city, identifying i) number of infected and; ii) numbers of deaths by COVID-19. In subdivision IV - Itoupavas, the Itoupava Central district has the highest number of contaminated (1,091), followed by the Itoupavazinha neighborhood (879). The highest number of deaths due to COVID-19 occurred in the neighborhood of Velha (13), (subdivision I - Velha). Data indicates that was the most populated neighborhoods where was most affected by the spread of the virus and had the highest number of deaths.

\subsection{Blumenau's social environmental vulnerability and its relationship to covid-19}

The data explored at this research shows that, in Blumenau, 71\% of the people who died f COVID 19 had a family income of less than 900 US\$ per month. $30 \%$ of the total deaths occurred among the population living in areas of average family income of up to 3 minimum brazilian wages (US\$ 526); 40\% for sites where the average is between 3 to 5 brazilian wages (US\$ 526 to US\$ 900); 19\% for sites where the average is 5 to 7 Brazilian wages (US\$ 900 to US\$ 1.228 ) and; $10 \%$ of the total number of death were at sites where family income average is over 7 brazilian wages. In addition, 93\% of people aged up to 50 years of age, who died of COVID-19, lived in areas with an average family income of 5 brazilian wages per month. Among the confirmed deaths of people over the age of $60,61 \%$ were in areas of social vulnerability.

The population density strongly influenced the spread of the virus throughout the territory and the number of deaths (Figure 3a). According to the mapping carried out, the most density areas of Blumenau had the highest number of contamination and deaths from COVID 19, particularly the districts of the subdivisions of Velha, Centro and Itoupavas. Another important factor for contamination was the population density per household. The regions where there were more people living in one house, were the areas where people earned less than 200 US\$ monthly and (5 brazilian wage), had high rates of contamination by COVID and COVID 19's deaths.

The population mapping over 45 years old superimposed on the spatialization data of deaths confirmed by COVID-19 (figure $3 b$ ), reveals that the areas with more inhabitants over 45 years old had a higher number of deaths. However, population over 60 years old, regardless of where they live, are the most vulnerable to the worsening of the symptoms of COVID-19 and the main fatal victims of the disease. Approximately $74 \%$ of the deaths confirmed by COVID-19 in Blumenau, up till the $30^{\text {th }}$ of September, were people over 60. Another 30 deaths occurred among people between 31 and 59 years old. Only 3 people died by COVID-19 under the age of 30 years old. 
Figure 3 - (a) Map of population density and (b) map of \% of people over 45 years old that dead by COVID-19 in Blumenau.
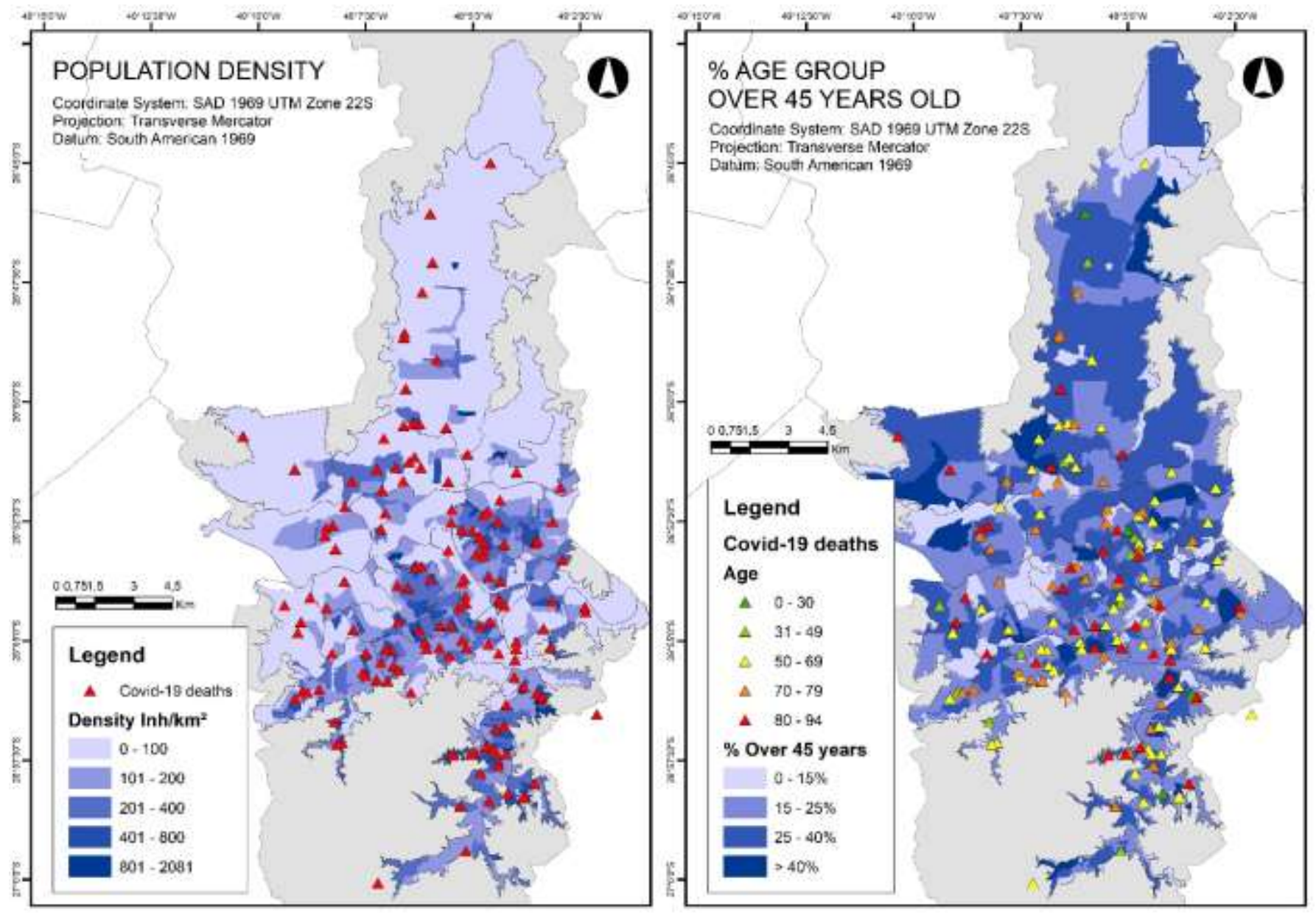

Source: Authors (2020), using data from the health surveillance of Blumenau (2020) until September 30; IBGE (2010).

Figure 4 shows the areas where there is hardly any sewage and lack of water (slums) and number of death by COVID19. The data show that $31 \%$ of the people who died by COVID-19 lived at slums without adequate sewage. The central regions of the city were the most impacted by the pandemic, $69 \%$ of the deaths. This fact is due to urbanization, that is, the health services, leisure, and education and so on, that situated at the Central ant it concentrates people mobility, connections and busses station. regions. But proportionally at the central there are more people than at the slum, that's why there were a higher number of death $(69 \%)$.

The map of risk areas (floods and landslides) and deaths by COVID-19 (Figure 4) shows that the highest number of deaths by COVID-19 lived at sites of high and very high environmental susceptibility. In addition, most of those infected with the disease also lived at these sites. The situation may get worst because there is a certain local resilience to hydrometeorological disasters, but there is short ability to deal with the combined action (extreme weather event and COVID-19). Some of the local communities are still recovering from the last flood and landslide event. 
Figure 4 - Map of Social Environmental Scenarios.
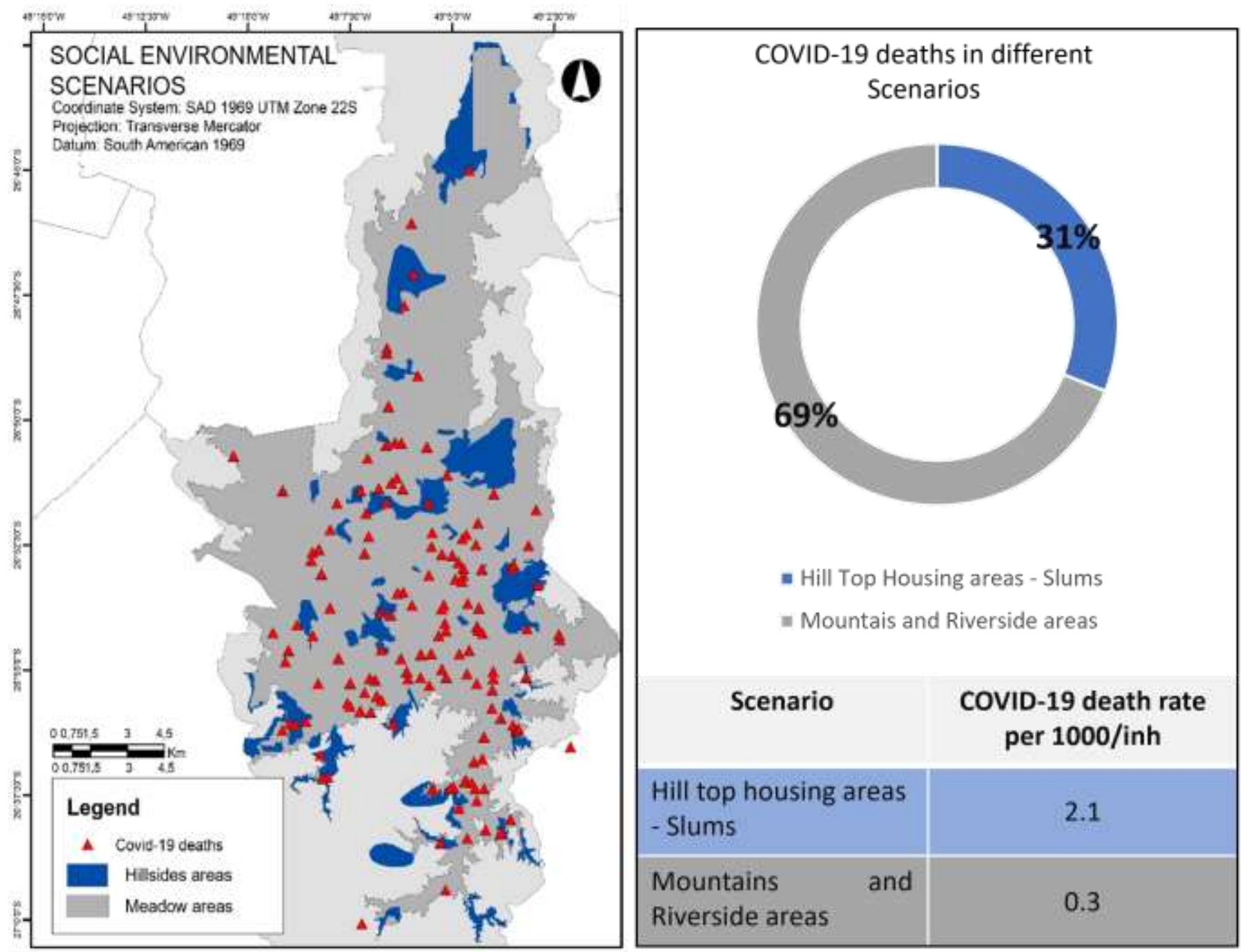

Source: Authors (2020), using data from the health surveillance of Blumenau (2020) until September 30 ${ }^{\text {th. }}$ PMB (2013).

When the pandemic arrived at Blumenau in March 2020, the dissemination of COVID-19 was more intense, at the Central sites of Blumenau, where floods and landslide had happened in the past and are likely to take place again. It is where family income is higher than at the other parts of the city and there is urban infrastructure. Afterwards, COVID-19 spreads at the suburbs, and at all regions of the city, mainly affecting the population of low income and at the age between 20 and 50 years old. The relationship between social environmental vulnerability in Blumenau and COVID-19 is characterized by: i) population of income below 5 minimum wages (900 dollars); ii) hardly any sanitary infrastructure; iii) areas susceptible to landslides; iv) more density populated sites and with more than of family at the same dwelling; v) population over 45 years old and vi) where busses are a way of transport. 
Figure 5 - Map of areas at risk of floods and landslides and COVID-19 deaths.

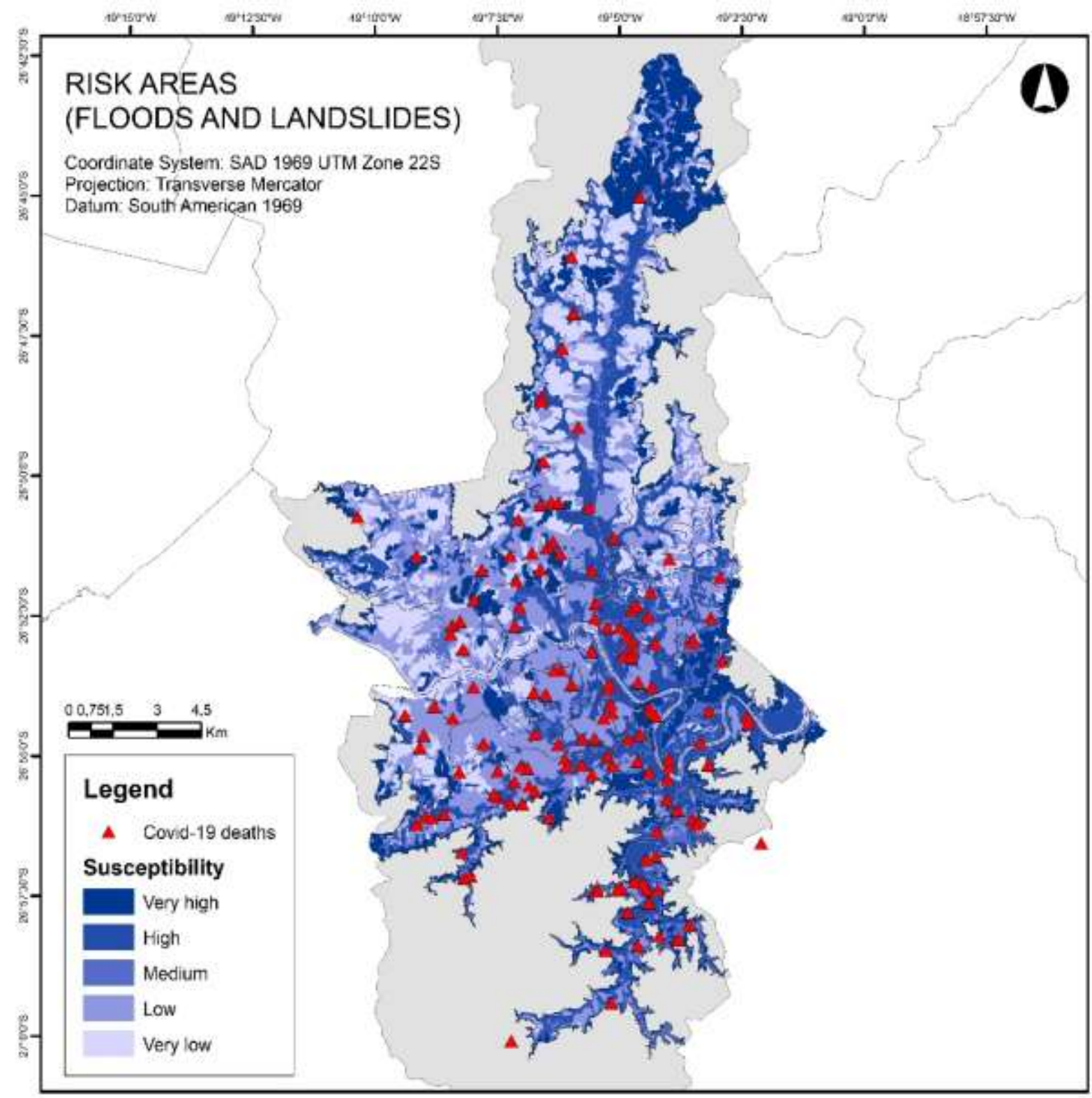

Source: Authors (2020), using data from the health surveillance of Blumenau (2020) until September 30; PMB (2013).

\section{Conclusion}

It is be argued that the social environmental impacts of the last decades are due to the consequences of the Anthropocene epoch. The pandemic caused by COVID-19 is one of those consequences. In order to slow down the impact of this pandemic, it is necessary to improve the Risk Management (RM) process and tools. Before the Risk management process application, one should consider a method of describing the system and assessment the risk. This article describes a research design made to study aspects of social environmental vulnerability that underlies the linkages between inequalities and COVID-19. After all, that the combined effect of environmental susceptibility (social environmental condition) and vulnerability (social economic condition) has a clear spread pattern. For this reason, the vulnerability to Covid-19 can intuitively reflect the social environmental vulnerability of the population. However, the analysis between risk indicators and number of deaths outlines a complex risk relationship. Therefore, it can be sad that a better understanding of the spatial 
distribution of social environmental vulnerability is important not only for situation of risk by epidemics, but also about extreme climatic events.

For this article, we have used a case study about the city of Blumenau, as a way to address the basic research questions: Is there a relationship between social environmental vulnerability and COVID-19 at Blumenau?

The analysis made shows that there is a strong relationship between the local social environment and the spread pattern of COVID-19 over Blumenau. The number of COVID19 cases is high and number of deaths as well, where social environment vulnerability is bad, considering the indicators included on the analysis. The death rate is high where there is no or hardly any urban infrastructure such as treated sewage; high density of people in the same house; low family income; and sites of high disasters risk. On the other hand, the analysis brought about that site where family income is high, contamination rate may be high as well, although death rate is low. At this context, the relations between socio environmental vulnerability and COVID-19 is similar as on a natural disaster. Disaster affects the entire city, democratically, but the poor are the ones to suffer and have the least capacity for prevention and response if we compare with the rest of the population. The challenge is to manage risk to natural disasters in the COVID-19 epoch. They both may happen at the same time. COVID-19 presents a new challenge for risk management. The combined increase in the effects of climate change and the social vulnerability of the population of Blumenau with the lack of resilience to face the pandemic is transforming its management very difficult. The management of the pandemic at this case is more and more necessary, but what is been done is frequently insufficient. Thus, it can be said that COVID-19 proves Blumenau's social environmental problems. In this sense, the study points out between June and August 2020, there were a progressive loss of control of the pandemic phenomenon in Blumenau.

It was found that there was an increase on the Blumenau's population social vulnerability, due to the catastrophic impacts of the COVID-19 pandemic. These impacts are characterized, in the first place, by the number of COVID-19's deaths, that resulted on the collapse of the Blumenau's public health system. Blumenau is currently facing a broad range of serious and growing resources and social issues. During the period of the research, the was an increase in the rate of unemployment, poverty, food insecurity, and so on. Santa Catarina, where Blumenau is situated, is facing a broad range of disasters, as well. In July 2020, it was registered an extratropical cyclone, that caused severe damage to the urban and electricity infrastructure. Flooding combined with landslides has also been a major threat at Blumenau/SC, that caused human lives and economic losses. Because of this combine disasters affects, it is suggested for the next study an assessment of the population's exposure level to the risks of disasters caused by combined events such as: flooding, mass landslide, cyclone and an epidemic. The aim of the next research would be to draw up a risk scenario for Blumenau, as well as to build a framework to identify sites that are more likely to be affected by disasters. The main purpose for future research, on our point of view, would be to build a socioenvironmental vulnerability index for Blumenau, and then, try to minimize socio-environmental unpredictability to disaster, based on statistical data.

\section{Acknowledgments}

Acknowledgements are made to the UNIVERSAL/MCTIC CNPQ/ 2018 scheme offered by the National Council for Scientific and Technological Development (CNPQ) that has made possible the research project "Arenas, disputes and challenges in the multiple water management arrangements", from which this paper came out. The appreciation is extended to the senior research grant given to Cristiane Mansur de Moraes Souza, PHD, by CNPQ (process 309115/2017-5), the PHD grant given by CAPES to Bruno Jandir Mello (FURB), and the research scholarship given by CNPQ to Patrícia Dornelles de Aguiar (2020-2021) that is linked to the mention research project. Authors gratefully acknowledge the support and financial assistance provided by CNPQ, Universidade Regional de Blumenau e Universidade Estadual da Paraíba. Acknowledgements are made to the Prefeitura Municipal de Blumenau, in particularly to João Vitor Kriger - Director of Social projects office, and 
to the Secretaria Municipal de Gestão Governamental (SEGG) and to the Serviço de Gestão da Educação na Saúde for the attention given to this research. They have provided the COVID-19 database.

\section{References}

Acselrad, H. (2018). Conflitos ambientais urbanos, vulnerabilidades e desigualdades. 390-404.

Adger, N. (2006). Vulnerability. Journal Global Environmental Change, 16(3), 268-281. https://doi.org/10.1016/j.gloenvcha.2006.02.006

Aylward, B. \& Liang, W. (2020). The WHO-China Joint Mission on Coronavirus Disease 2019. https://www.who.int/docs/default-source/coronaviruse/whochina-joint-mission-on-covid-19-final-report.pdf

Beck, U. (2015) Emancipatory catastrophism: What does it mean to climate change and risk society? Current Sociology, 63(1), 75-88. https://doi.org/10.1177/0011392114559951

Beck, U. (1999). World risk Society. Policy Press, Cambridge.

Campbell, D. (2015). What is climate change policy now trying to achieve? Economic Affairs, 35(3), 428-442. https://doiorg.ez71.periodicos.capes.gov.br/10.1111/ecaf.12143

CEMADEN - Centro Nacional de Monitoramento e Alertas de Desastres Naturais (2018). Estimation of exposed population to landslides and floods risk areas in brazil, on an intra-urban scale. International journal of disaster risk reduction, 31. https://doi.org/10.1016/j.ijdrr.2018.06.002

Crutzen, P. \& Stoermer, E. F. (2000). The Anthropocene. Global Change Newsletter of International Geosphere-Biosphere Programme, 41, 17-18. http://dx.doi.org/10.1579/0044-7447(2007)36[614:TAAHNO]2.0.CO;2

Cutter, S. (2006). Hazards, vulnerability and environmental justice. Earthscan.

Cutter, S. (2011). A ciência da vulnerabilidade: modelos, métodos e indicadores. Revista Crítica de Ciências Sociais, 93, 59-69. https://doi.org/10.4000/rccs.165

Dalby, S. (2015). Anthropocene formations: environmental security, geopolitics and disaster. Theory, Culture \& Society, 1-20. https://biglobalization.org/sites/default/files/uploads/files/big_research_project_80_sustainability_dalby.pdf

De Paula, D. P., Medeiros, D. H. M., Barros, E. L., Guerra, R. G. P., Santos, J. O., Lima, J. S. Q. \& Monteiro, R. M. L. (2020) Diffusion of Covid-19 in the Northern Metropolis in Northeast Brazil: territorial dynamics and risks associated with Social Vulnerability. Sociedade \& Natureza, 32, 639-656. https://doi.org/10.14393/SN-v32-2020-56098

EPAGRI - Empresa de Pesquisa Agropecuária e Extensão Rural de Santa Catarina (2020). Vulnerabilidade Social, Redes Agrícolas e o Covid19. https://www.arcgis.com/apps/View/index.html?appid=ba7489fd1cf546fcba6093ccc3c8fab0\&extent=-59.6514,-32.0751,-42.7764,-25.1174

Ferguson, N. M. et al. (2020). COVID-19 reports. Imperial College COVID-19 Response Team, 1-20. https://doi.org/10.25561/77482

Fitz, P. R. (2008). Geoprocessamento sem complicação. Oficina de Textos.

Goldblatt, D. (1996). Teoria social do ambiente. Piaget

Herculano, S. (2020). Resenhando o debate sobre Justiça Ambiental: produção teórica, breve acervo de casos e criação da Rede Brasileira de Justiça Ambiental. Desenvolvimento e Meio Ambiente (UFPR), 1(5), 143-149.

Instituto Brasileiro de Geografia e Estatística - IBGE. (2010). Cidades. https://cidades.ibge.gov.br/

Instituto Brasileiro de Geografia e Estatística - IBGE. (2019) Projeções da população: Brasil e unidades da Federação, revisão 2019. https://www.ibge.gov.br/estatisticas/sociais/populacao/9109-projecao-da-populacao.html

LAGOM DATA. (2010). Vítima-Padrão de COVID-19 No Brasil. https://epoca.globo.com/sociedade/dados-do-sus-revelam-vitima-padrao-de-covid-19-nobrasil-homem-pobre-negro-2451341

Ludke, M. \& André, M. E. D. A. (2013). Pesquisas em educação: uma abordagem qualitativa. E.P.U.

Ludwig, L. \& Mattedi, M. A. (2016). Dos desastres do desenvolvimento, ao desenvolvimento dos desastres. Desenvolvimento e Meio Ambiente, 39, $23-42$. http://dx.doi.org/10.5380/dma.v39i0.45575

Mahaffy, P. G. (2014) Telling time: chemistry education in the anthropocene epoch. Journal of Chemical Education, 91, 463-465.10.1021/ed5001922, 0.76.

MA - Millennium Ecosystem Assessment (2005). Ecosystem and human well-being: synthesis. Island Press, Washington. https://www.millenniumassessment.org/documents/document.356.aspx.pdf

Moore, M., Gelfeld, B., Okunogbe, A. T. \& Paul, C. (2017). Identifying Future Disease Hot Spots: Infectious Disease Vulnerability Index. Rand Health, 6(3). Retrieved from https://www.ncbi.nlm.nih.gov/pmc/articles/PMC5568150/

Moser, C. (1998). The asset vulnerability framework: reassessing urban poverty reduction strategies. World development, 26, (1), 1-19. https://doi.org/10.1016/S0305-750X(97)10015-8 
Research, Society and Development, v. 10, n. 10, e161101018739, 2021

(CC BY 4.0) | ISSN 2525-3409 | DOI: http://dx.doi.org/10.33448/rsd-v10i10.18739

Pereira, A. S. et al. (2018). Metodologia da pesquisa cientifica. UFSM. https://repositorio.ufsm.br/bitstream/handle/1/15824/Lic_Computacao_MetodologiaPesquisa-Cientifica.pdf?sequence $=1$.

PMB - Prefeitura Municipal de Blumenau. (2013). Mapas de Blumenau (SC). Retrieved from https://www.blumenau.sc.gov.br/governo/secretaria-dedesenvolvimento-urbano/pagina/mapas-seplan

PMB - Prefeitura Municipal de Blumenau - PMB (2020). Boletim COVID-19. Retrieved from https://www.blumenau.sc.gov.br/secretarias/gabinete-doprefeito/gapref/boletim-coronavairus-blumenau-25-07-202121

Reyers, B., Biggs, R., Cumming, G. S., Elmqvist, T., Hejnowicz, A. P. \& Polasky, S. (2013). Getting the measure of ecosystem services: a social-ecological approach. Frontiers in Ecology and the environment, 11, 268-273. http://www.jstor.org/stable/23470507

Rodríguez, J. (2001). Vulnerabilidad y grupos vulnerables: un marco de referencia conceptual mirando a los jóvenes. CEPAL (Serie Población y Desarrollo). Retrieved from https://repositorio.cepal.org/bitstream/handle/11362/7150/S018659_es.pdf

Santa Catarina. (2020). Boletim novo Coronavírus. Retrieved from http://www.coronavirus.sc.gov.br/boletins/

Selltiz, C., Wrightsman, L.S \& Cook, S. W. Métodos de pesquisa das relações sociais. Herder, 1965.

Silva, J. B. D. A., \& Muniz, A. M. V. (2020). Pandemia do Coronavírus no Brasil: impactos no território cearense. Espaço e Economia, 17, 1-19. http://dx.doi.org/10.4000/espacoeconomia.10501

Steffen, P. J. W., Crutzen, P. J. \& Mcneill, J. R. (2007). The Anthropocene: are humans now overwhelming the great forces of nature? Ambio - Royal Swedish Academy of Science, 36 (8). http://dx.doi.org/10.1579/0044-744792007)36[614:TAAHNO]2.0.CO;2

Yin, R.K. (2015). O estudo de caso. Bookman.

Walker, B. \& Salt, D. (2006). Resilience thinking: sustaining ecosystems and people in a changing world. Island press.

WHO - World Health Organization - (2020). Responding to community spread of COVID-19. Interim Guidance. https://apps.who.int/iris/rest/ bitstreams/1271989/retrieve

Wu, Y., Guo, C., Tang, L., Hong, Z., Zhou, J., Dong, X., Yin, H., Xiao, Q., Tang, Y., Qu, X., Kuang, L., Fang, X., Mishra, N., Lu, J., Shan, H., Jiang, G. \& Huang, X. (2020). Prolonged presence of SARS-CoV-2 viral RNA in fecal samples. The Lancet Gastroenterology \& Hepatology, 5(5), 434-435. $10.1016 / \mathrm{S} 2468-1253(20) 30083-2$ 